\title{
Flood risk spatial index analysis in the coastal Pekalongan, Central Java, Indonesia
}

\author{
Ratna Mustika Anindita*, Indah Susilowati, and Fuad Muhammad \\ Environmental Science, Postgraduate School, Diponegoro University, Semarang, Indonesia
}

\begin{abstract}
The North coast of Java is increasingly exposed to flood risks due to land subsidence and climate change, resulting in sea-level rise. This paper developed a flood risk spatial index model in the coastal Pekalongan. The model was systematically arranged from various flood risk indicators related to the social, economic, and environment of coastal Pekalongan based on surveys and interviews with the communities and regional governments. These indicators are then integrated into hazard and vulnerability as components of risk. Using the index system method and ArcGIS, the risk index is classified into five levels (very high, high, medium, low, very low) and generated into a flood risk spatial distribution map. We found that the risk in the study area varies between a medium to a very high level of risk. The very high level of risk was located in Tratebang, Pecakaran, and Tegaldowo Village. A risk spatial distribution map can be used to evaluate potential risks and flood mitigation.
\end{abstract}

Keywords: flood risk index, ArcGIS, Pekalongan

\section{Introduction}

Climate change is an inevitable event. That happens not only because of nature but also from anthropogenic factors. Climate change can increase the threat of disasters, one of which is flooding. Flood has become the most common disaster that often occurs and has a more dangerous effect than other disasters [1]. In the last few decades, the north coast of Java has encountered floods, one of which is Pekalongan. The coastal Pekalongan is not only affected by rain floods but also through the tidal flood. Tidal flooding in Pekalongan has occurred almost every day for the past 10 years and mainly affects villages bordering the sea [2].

The impact of climate change through sea-level rise has a tendency for coastal areas to be flooded, consequently, the coastal area's balance will also be disturbed [3]. On the other hand, land subsidence is also a cause of flooding in the coastal Pekalongan. Land

* Corresponding author: ratnamustikaa@gmail.com 
subsidence is caused by natural compacting of young sediments in the alluvial plains that form the coastal area, which is accelerated by anthropogenic factors such as uncontrolled groundwater extraction and pressure from building and infrastructure. Land subsidence is also an accumulation of excessive groundwater exploitation from various human activities such as agriculture, industry, and community needs [4]. The number of locations of deep groundwater wells that are scattered in the area of tidal floods worsens the condition of the tidal flood [5]. The various factors above increase the risk of disasters in the coastal Pekalongan, so mapping and analyzing flood risk (R) needs to be carried out.

In discussions regarding the "loss and impact" of the flood disaster, risk assessment methods received special attention. Flood risk evaluation and development of a comprehensive disaster risk map that illustrates its characteristics in each village is needed by governments to carry out planning, such as land use and infrastructure development. Therefore, it is important to develop spatial index model of flood risk in the coastal Pekalongan. The flood risk spatial index model, in the form of this map, can help governments as policymakers, scientists, and professionals in the industry to estimate potential risks and increase general awareness on flood risk mitigation.

\section{Study area}

The research location uses a Landscape-based Perspective approach implemented in the villages in the coastal Pekalongan as a prototype of the study area in Central Java Province as shown in Fig. 1. The study area includes 2 sub-districts (9 villages) in Pekalongan City and 2 sub-districts (13 villages) in Pekalongan Regency. Study areas include Pekalongan Utara, Pekalongan Barat, Wonokerto, and Tirto Sub-Districts.

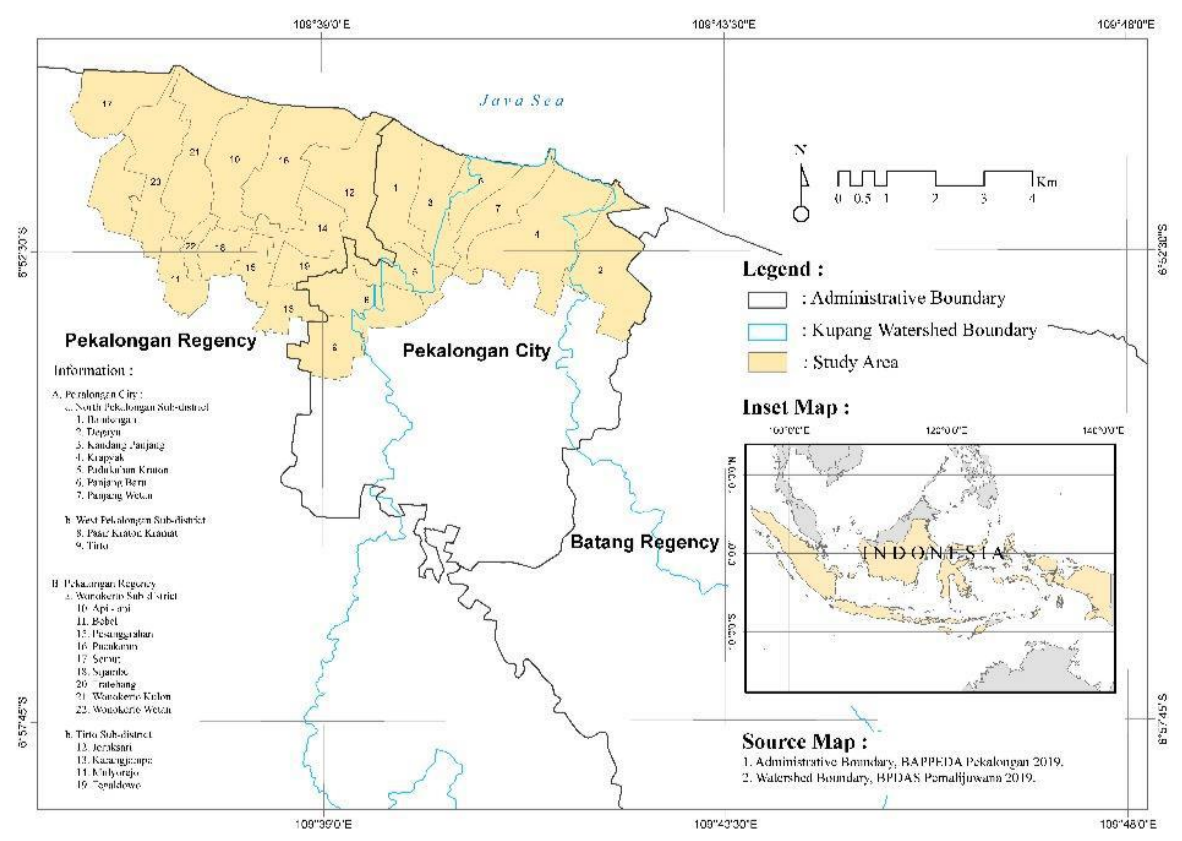

Fig. 1. Study Area. 


\section{Methodology}

\subsection{Developing indices}

The IPCC [6] defines disaster risk as a possibility that occurs during a certain period of drastic changes due to dangerous physical events that interact with vulnerable social conditions, which affects human, material, economic, and environmental losses. Therefore, immediate response and external support are needed for recovery. One of the causes of disasters is climate change. Based on this definition, disaster risk $(\mathrm{R})$ can be written as:

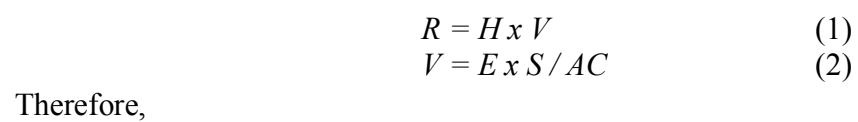

$$
R=H x E x S / A C
$$

where $\mathrm{H}$ represents Hazard, V represent Vulnerability, S represents Sensitivity, E represents Exposure, and AC represents Adaptive Capacity [6, 7, 8].

\subsubsection{Hazard index}

Hazard $(\mathrm{H})$ is defined as a dangerous phenomenon, substance, human activity or condition that may cause loss of life, injury or other health impacts, property damage, loss of livelihoods and services, social and economic disruption, or environmental damage [7]. Several hazard indicators used in flood disasters are flood frequency, flood height, flood duration, the likelihood of inundation, or damage due to previous floods [8]. The Hazard index $(\mathrm{H})$ in this study was arranged based on 4 components (Table 1). Each component selected to represent the danger of each village in the coastal Pekalongan.

Table 1. Hazard Index Components.

\begin{tabular}{|c|l|}
\hline No. & \multicolumn{1}{|c|}{ Components } \\
\hline 1 & Flood type (tidal floods and / or rain floods) \\
\hline 2 & Frequency of flood events \\
\hline 3 & Flood height \\
\hline 4 & Flood duration \\
\hline
\end{tabular}

Source : $[8,9]$

\subsubsection{Sensitivity index}

The sensitivity of a system to disasters reflects the extent to which a system is affected, either adversely or profitably. The effect can be direct (e.g. changes in yields in response to changes in temperature variability) and indirect (e.g. damage caused by an increase in the frequency of coastal flooding due to sea-level rise) [10]. The sensitive system is more responsive too small changes. The Sensitivity index (S) in this paper is arranged based on 10 components where each component is formed from indicators selected to represent the sensitivity in the coastal Pekalongan (Table 2). 
Table 2. Sensitivity Index Components.

\begin{tabular}{|c|c|c|}
\hline No. & Components & Indicators \\
\hline 1 & $\begin{array}{l}\text { Infrastructure and } \\
\text { settlements }\end{array}$ & $\begin{array}{l}\text { a. Percentage of non-permanent buildings (houses that are } \\
\text { not strong enough to withstand disasters) }(\%)\end{array}$ \\
\hline 2 & Spatial planning & b. Percentage of a green area $(\%)$ \\
\hline 3 & Poverty & c. Poor population ratio $(\%)$ \\
\hline \multirow[t]{4}{*}{4} & \multirow[t]{4}{*}{ Vulnerable Group } & d. The ratio of the female population (Gender) (\%) \\
\hline & & e. The ratio of the elderly population ( $>60$ years) $(\%)$ \\
\hline & & f. The ratio of children's population $(<12$ years $)(\%)$ \\
\hline & & g. The ratio of the disabled population $(\%)$ \\
\hline \multirow[t]{2}{*}{5} & \multirow[t]{2}{*}{ Income per capita } & h. The income per capita level (mn/year) \\
\hline & & $\begin{array}{l}\text { i. Percentage of } \mathrm{HH} \text { whose members work in agriculture, } \\
\text { aquaculture, or fishery to the total livelihood per } \\
\text { village } \\
(\%) \text {. }\end{array}$ \\
\hline 7 & Land ownership & j. Percentage of $\mathrm{HH}$ that do not have land ownership (\%) \\
\hline 8 & Health & $\begin{array}{l}\text { k. The number of water-borne diseases incidents per } \\
\text { district. }\end{array}$ \\
\hline 10 & Critical Assets & $\begin{array}{l}\text { 1. Amount of critical assets damaged/affected by floods } \\
\text { (health, infrastructure, markets, energy, transportation, } \\
\text { etc.) }\end{array}$ \\
\hline 13 & GDPR by sector & $\begin{array}{l}\text { m. Percentage of GDP contribution per sector affected } \\
\text { (aquaculture ponds and agriculture) per district }\end{array}$ \\
\hline 14 & $\begin{array}{l}\text { Infrastructure, } \\
\text { facilities, and } \\
\text { utilities }\end{array}$ & n. Road classes (transportation) that are often affected \\
\hline
\end{tabular}

Source : [11-14]

\subsubsection{Exposure index}

Exposure is defined by people, properties, systems, or other elements present in hazard zones that are subject to potential losses [7]. Exposure index (E) in this paper is compiled based on 8 components where each component is formed from the indicators selected to represent the level of exposure of each village in the coastal Pekalongan (Table 3). 
Table 3. Exposure Index Components.

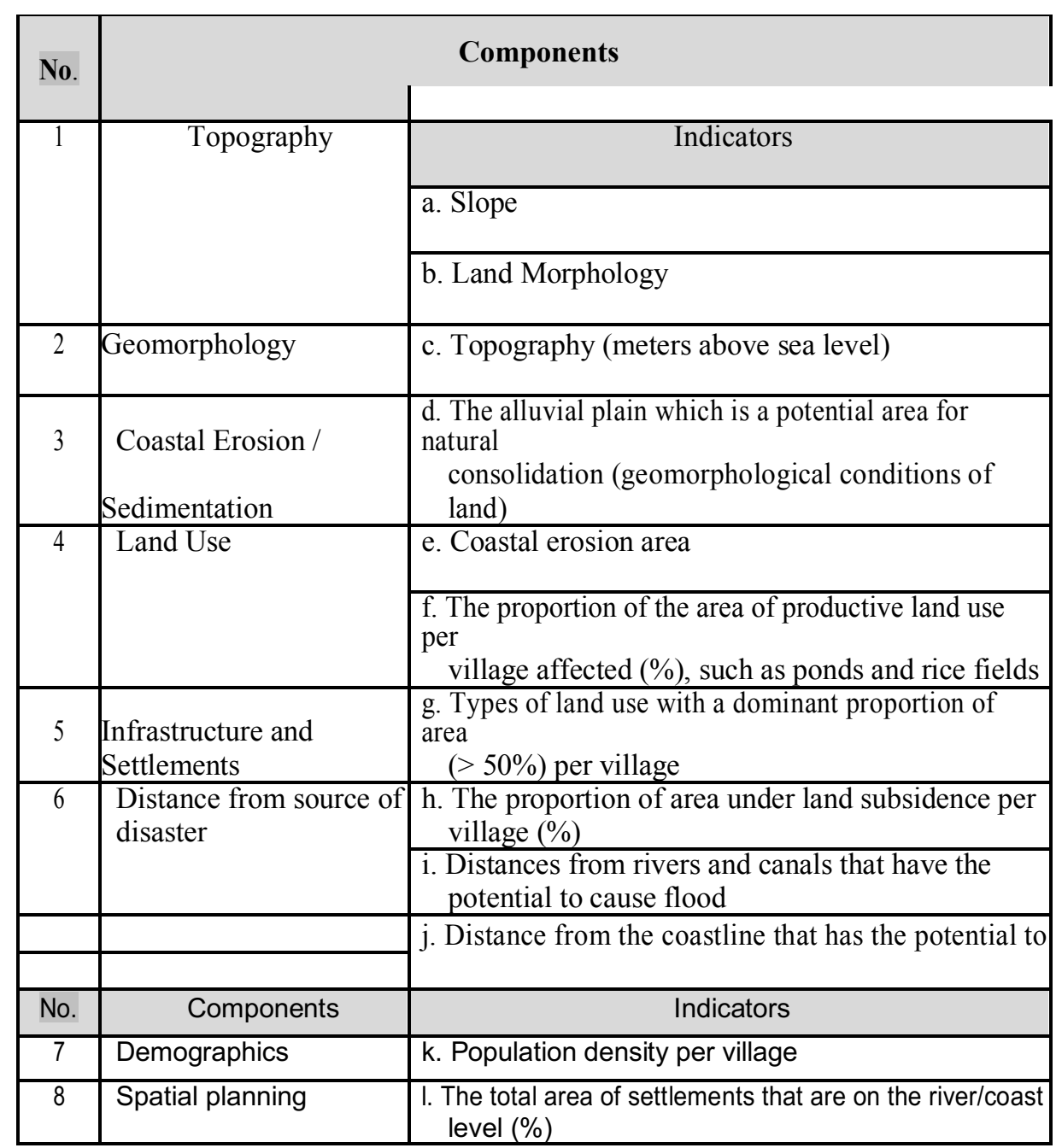

Source : [12]

\subsubsection{Adaptive capacity sub-index}

The IPCC [10] defines adaptive capacity as the ability of systems to adapt to climate change, both by taking advantage of the opportunities and overcoming the consequences. Some recent literature emphasizes the importance of socioeconomic factors and the role of governments and institutions in determining the ability to adapt to climate change $[15,16$, 17]. The Adaptive Capacity Index (AC) in this study was compiled based on 15 components formed from 31 indicators. Each of these components is formed from indicators compiled and selected to be able to represent the adaptability of each village in the coastal Pekalongan (Table 4). 
Table 4. Adaptive Capacity Index Components.

\begin{tabular}{|c|c|c|}
\hline No. & Components & Indicators \\
\hline \multirow[t]{2}{*}{1} & \multirow[t]{2}{*}{ Regulation and Planning } & $\begin{array}{l}\text { a. Regulatory support from the aspect of spatial } \\
\text { planning }\end{array}$ \\
\hline & & b. Floods management in the RPJM \\
\hline 2 & Disaster Financing & c. Regional financial support in handling floods \\
\hline \multirow[t]{2}{*}{3} & \multirow[t]{2}{*}{ Disaster Early Warning } & d. The existence of floods early warning system \\
\hline & & $\begin{array}{l}\text { The existence of tidal floods early warning } \\
\text { e. system }\end{array}$ \\
\hline \multirow[t]{2}{*}{4} & \multirow[t]{2}{*}{ Disaster Service Centers } & $\begin{array}{l}\text { f. The existence of an information service center on } \\
\text { flood disasters }\end{array}$ \\
\hline & & $\begin{array}{l}\text { g. The quality of government services/agencies in } \\
\text { preparedness to deal with floods }\end{array}$ \\
\hline \multirow[t]{2}{*}{5} & \multirow[t]{2}{*}{$\begin{array}{l}\text { Institutional in the form of } \\
\text { Community Groups }\end{array}$} & $\begin{array}{l}\text { h. The existence of community groups that alert } \\
\text { disaster }\end{array}$ \\
\hline & & $\begin{array}{l}\text { i. The background of the formation of community } \\
\text { groups resilient / disaster preparedness, such as KSB } \\
\text { (Disaster Preparedness Group), TSBK (Village } \\
\text { Disaster Preparedness Team), SIBAT (Community } \\
\text { Based Disaster Preparedness, etc. }\end{array}$ \\
\hline \multirow[t]{2}{*}{6} & \multirow[t]{2}{*}{ Disaster Program } & j. Existence of disaster mitigation programs \\
\hline & & $\begin{array}{l}\text { Existence of conservation/rehabilitation programs } \\
\text { k. to } \\
\text { deal with floods }\end{array}$ \\
\hline \multirow[t]{2}{*}{7} & \multirow[t]{2}{*}{$\begin{array}{l}\text { Education, Counseling, and } \\
\text { Community Knowledge }\end{array}$} & $\begin{array}{l}\text { The ratio of higher education level (high school } \\
\text { 1. to } \\
\text { university) }\end{array}$ \\
\hline & & m. Counseling and assistance for flood countermeasures \\
\hline 8 & Disaster mitigation & n. Village-scale disaster management plan document \\
\hline
\end{tabular}




\begin{tabular}{|c|c|c|}
\hline No. & Components & Indicators \\
\hline & & $\begin{array}{l}\text { O. Documents and implementation of RAD PRB } \\
\text { (Regional Action Plan for Disaster Risk Reduction) } \\
\text { of BPBD }\end{array}$ \\
\hline \multirow[t]{6}{*}{9} & \multirow{6}{*}{$\begin{array}{l}\text { Preparedness and } \\
\text { Contingencies }\end{array}$} & p. Plans and stages of flood preparedness activities \\
\hline & & $\begin{array}{l}\text { q. The existence of SOPs in a state of emergency flood } \\
\text { disaster }\end{array}$ \\
\hline & & $\begin{array}{l}\text { r. The speed of implementation of government/agency } \\
\text { emergency response during flood events. }\end{array}$ \\
\hline & & $\begin{array}{l}\text { S. Plans and stages of preparedness activities to deal } \\
\text { with tidal/tidal floods }\end{array}$ \\
\hline & & $\begin{array}{l}\text { t. The existence of SOPs in a state of emergency } \\
\text { (contingency) for flood / tidal floods }\end{array}$ \\
\hline & & $\begin{array}{l}\text { u. The speed of implementation of the emergency } \\
\text { response of the government/agency during the tidal } \\
\text { flood. }\end{array}$ \\
\hline 10 & Flood Control Infrastructure & $\begin{array}{l}\text { v. The presence of polders, retention ponds, sea dikes, } \\
\text { etc. }\end{array}$ \\
\hline 11 & $\begin{array}{l}\text { Community Perceptions of } \\
\text { Floods }\end{array}$ & $\begin{array}{l}\text { W. Direct perception (response/acceptance) of the } \\
\text { community towards flood and tidal management } \\
\text { programs }\end{array}$ \\
\hline 12 & Local culture & X. Local wisdom related to flood and tidal disasters \\
\hline 13 & Welfare & y. Percentage of the number of prosperous families \\
\hline \multirow[t]{5}{*}{14} & \multirow[t]{5}{*}{$\begin{array}{l}\text { Infrastructure, Facilities, and } \\
\text { Utilities }\end{array}$} & $\begin{array}{l}\text { z. Availability of education supporting facilities and } \\
\text { infrastructure }\end{array}$ \\
\hline & & $\begin{array}{l}\text { aa. Percentage of } \mathrm{HH} \text { in 'main fuel use' for cooking per } \\
\text { village }(\%)\end{array}$ \\
\hline & & $\begin{array}{l}\mathrm{bb} \text {. Limited clean water source facilities (percentage of } \\
\text { families that do not use PAM / PDAM water } \\
\text { sources) }\end{array}$ \\
\hline & & $\begin{array}{l}\text { cc. Quality of drainage (environmental/tertiary) in the } \\
\text { administrative area of the village }\end{array}$ \\
\hline & & $\begin{array}{l}\text { dd. Percentage of households that have proper sanitation } \\
\text { facilities in the village / administrative area. }\end{array}$ \\
\hline 15 & Health insurance & $\begin{array}{l}\text { ee. The proportion of poor people who have health } \\
\text { insurance such as KIS (Kartu Indonesia Sehat) / } \\
\text { BPJS }\end{array}$ \\
\hline
\end{tabular}

Source : $[11,12,13]$ 


\subsection{Data collection}

This paper used primary and secondary data. Primary data consist of village office statistical data, questionnaire surveys, direct observation, and thorough analysis of geospatial data with GIS. The questionnaire survey was conducted on the key person who mastered the problem of flooding, and representatives of the city government, district government, village, gender, and community. Questionnaire surveys for the government were carried out at Bappeda (Regional Planning and Development Agency), BPBD (Regional Disaster Management Agency), Public Works Offices, and Health Offices. Whereas secondary data was obtained from the Central Statistics Agency.

\subsection{Calculating indices}

The index is obtained from the total of the multiplication of the weight values and indicators of each component used. The calculation of the total index value uses the following function:

$$
T I=[(w 1 \times s 1)+(w 2 \times s 2)+\ldots+(w n \times s n)]
$$

where TI represents total index, w represents weight, and s represents score

The results of the risk spatial model are classified into 5 index classes using data normalization so that each data used has a range between $1-5$. Classification is done by proportionally dividing the value of risk into five classes (very high, high, medium, low, very low).

\section{Results and discussion}

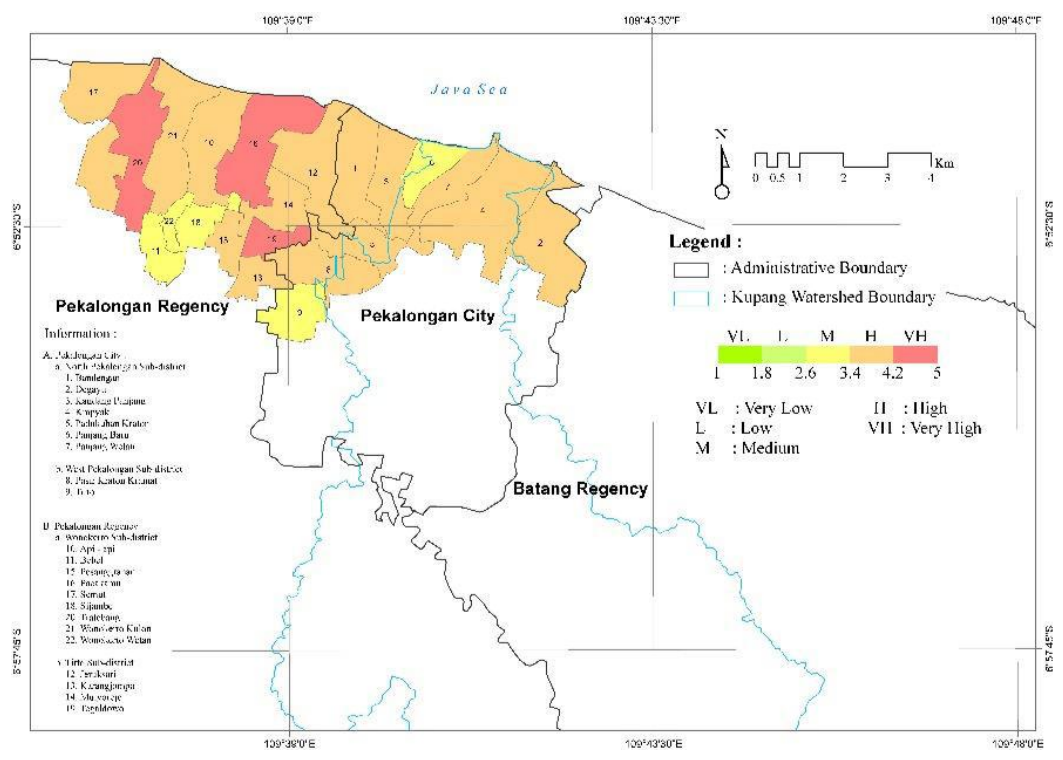

Fig. 2. Spatial distribution risk index map (2020) 
From the results of the hazard and vulnerability index calculation, the value of flood risk in 22 villages in the coastal Pekalongan city and Pekalongan regency was shown in Fig. 2. It shows the level distribution of flood risk at very high, high, and medium level. The hot spot area is a village with a "very high" risk level and is spread in 3 villages. Outside the hot spot area, there are 14 villages with a "high" level of risk and 5 villages with a "medium" level of risk. The grouping of risk levels per sub-district was shown in Table 5.

Table 4. Risk Levels in Sub-Districts and Villages (2020)

\begin{tabular}{|c|c|c|c|c|c|c|}
\hline & \multicolumn{5}{|c|}{ Risk Levels } \\
\hline & & $\begin{array}{l}\text { Very } \\
\text { Low }\end{array}$ & Low & Medium & High & Very High \\
\hline \multirow{4}{*}{$\Xi \frac{\mathscr{L}}{\mathrm{C}}$} & $\begin{array}{l}\text { North } \\
\text { Pekalongan }\end{array}$ & - & - & $\begin{array}{l}\text { - Panjang } \\
\text { Baru }\end{array}$ & $\begin{array}{l}\text { - Degayu } \\
\text { - Bandengan } \\
\text { - Krapyak } \\
\text { - Kandang Panjang } \\
\text { - Panjang Wetan } \\
\text { - Padukuhan Kraton }\end{array}$ & - \\
\hline & $\begin{array}{l}\text { West } \\
\text { Pekalongan }\end{array}$ & - & - & - Tirto & $\begin{array}{l}\text { - Pasir Kraton } \\
\text { Kramat }\end{array}$ & - \\
\hline & Wonokerto & - & - & $\begin{array}{l}\text { - Bebel } \\
\text { - Sijambe } \\
\text { - Wonokerto } \\
\text { Wetan }\end{array}$ & $\begin{array}{l}\text { - Api-api } \\
\text { - Pesanggrahan } \\
\text { - Semut } \\
\text { - Wonokerto Kulon }\end{array}$ & $\begin{array}{l}\text { - Pecakaran } \\
\text { - Tratebang }\end{array}$ \\
\hline & Tirto & - & - & & $\begin{array}{l}\text { - Jeruksari } \\
\text { - Karangjompo } \\
\text { - Mulyorejo }\end{array}$ & - Tegaldowo \\
\hline
\end{tabular}

In Fig. 2, the hot spot area covers 3 villages, namely Pecakaran, Tratebang, and Tegaldowo. From the Hazard index, Pecakaran and Tegaldowo have a "very high" hazard level because both villages experience tidal floods and rain floods each week with a flood water level of approximately $25 \mathrm{~cm}$ and are inundated for an average of 24 hours. Tratebang village has a "high" level of hazard because it only experiences rain floods. Tidal floods have not occurred in this village since the existence of a sea dike that holds seawater from entering the village.

In terms of vulnerability, Pecakaran, Tratebang, and Tegaldowo Villages have a very high level of vulnerability. This is because the level of community welfare is low and the majority of the village infrastructure is flooded. Also, this condition is exacerbated by the absence of an early warning system for floods, disaster mitigation programs, and local wisdom of the people of the area.

The "very-high" hazard level in the Pecakaran and Tegaldowo Villages and the "high" hazard level in Tratebang Village, followed by a "very high" level of vulnerability, making flood risk in these villages at "very high" level. Special measures are needed from the 
government and related stakeholders to minimize flood risks in these villages. Some steps as follows: (1) carry out activities that can increase community productivity to reduce poverty ratios, (2) improve health quality to reduce the number of incidents of waterborne diseases, (3) manage important assets to overcome critical amounts of assets damaged/affected by flooding, (4) implement early warning systems for floods, (5) organize disaster mitigation programs, and (6) increase local wisdom in the community.

In addition to the hotspot area, there are 14 villages with high risk and 5 villages with medium risk. Fourteen villages with a high level of risk mostly border directly on the shoreline, so that seawater can easily inundate the village when it is high tide. However, there is one village, which is directly adjacent to the coast which has a "medium" level of risk, namely Panjang Baru Village. This is due to the "high" level of adaptive capacity even with a "high" level of hazard and exposure. Several factors that encourage high adaptive capacity, namely the existence of Disaster Services Center, disaster mitigation programs, counselling and assistance for flooding, preparedness to deal with floods, as well as health insurance.

\section{References}

1. L. Sundermann, O. Schelske, P. Hausmann, Mind the risk - A global ranking of cities under threat from natural disasters, (2014)

2. F.D.S Kartika, M. Helmi, Amirudin, Meta-analysis of community's adaptation pattern with tidal flood in Pekalongan City, Central Java, Indonesia, E3S Web of conferences 125 (2019)

3. S. Sunaryo, A. Ambariyanto, D.N. Sugianto, M. Helmi, A.H. Kaimuddin, A. Indarjo, Risk Analysis of Coastal Disaster of Semarang City, Indonesia, E3S Web of conferences 31 (2017)

4. BPS Kota Pekalongan, Kota Pekalongan dalam Angka 2018, (2018)

5. H. Andreas, H. Abidin, H.Z., D. Pradipta, Adaptation of “ Early Climate Change Disaster " to the Northern Coast of Java Island Indonesia. (2018)

6. IPCC, Managing the risks of extreme events and disasters to advance climate change adaptation, A Special Report of Working Groups I and II of the Intergovernmental Panel on Climate Change, (2012)

7. UNISDR, Terminology on Disaster Risk Reduction, UN, (2009)

8. I.A. Rana, J. K. Routray, Actual vis-à-vis Perceived Risk of Flood Prone Urban Communities in Pakistan, International Journal of Disaster Risk Reduction, (2016)

9. R.K. Waghwala, P.G. Agnihotri, Flood risk assessment and resilience strategies for flood risk management: A case study of Surat City, International Journal of Disaster Risk Reduction 40 (2019)

10. IPCC, Climate change 2007: The physical science basis, Contribution of Working Group I to the Fourth Assessment Report of the Intergovernmental Panel on Climate Change, (2007) 
11. K.U. Shah, H.B. Dulal, C. Johnson, A. Baptiste, Understanding livelihood vulnerability to climate change: Applying the livelihood vulnerability index in Trinidad and Tobago, Geoforum 47 (2013)

12. BNPB, Peraturan Kepala Badan Nasional Penanggulangan Bencana Nomor 02 Tahun 2012 tentang Pedoman Umum Pengkajian Risiko Bencana, (2012)

13. S.W.M. Weis, V.N. Agostini, L.M. Roth, B. Gilmer, S.R. Schill, J.E. Knowles, R. Blyther, Assessing vulnerability: an integrated approach for mapping adaptive capacity, sensitivity, and exposure, Climatic Change, (2016)

14. D. Zhang, X. Shi, H. Xu, Q. Jing, X. Pan, T. Liu, H. Wang, H. Hou, A GIS-based spatial multi-index model for flood risk assessment in the Yangtze River Basin, China. Environmental Impact Assessment Review 83 (2020) 
15. W.N. Adger, S. Agrawala, M.M.Q Mirza, C. Conde, K. O’Brien, J. Pulhin, R. Pulwarty, B. Smit, K. Takahashi, Assessment of adaptation practices, options, constraints and capacity, In M.L. Parry, O.F. Canziani, J.P. Palutikof, P.J. van der Linden, C.E. Hanson, eds. Climate Change 2007: Impacts, Adaptation and Vulnerability. Contribution of Working Group II to the Fourth Assessment Report of the Intergovernmental Panel on Climate Change, pp. 717-743 (2007)

16. N.L. Eagle, Adaptive capacity and its assessment, Global Environmental Change, 21: 647-656 (2011)

17. T. Williamson, H. Hesseln, M. Johston, Adaptive capacity deficits and adaptive capacity of economic systems in climate change vulnerability assessment, Forest Policy and Economics 15: 160-166, (2012) 